\title{
Proper Venue for Post-Trial Rule 41(e) Motions to Return Seized Property
}

\author{
Dov P. Grossman $\dagger$
}

Consider the following scenario: a defendant in a federal criminal case is tried and acquitted in the Middle District of North Carolina.' After her trial, the defendant moves in the trial court under Federal Rule of Criminal Procedure 41(e) ("Rule 41(e)") for the return of certain property ${ }^{2}$ seized by the government in relation to her prosecution. ${ }^{3}$ Federal agents seized the property during a portion of the criminal investigation that took place in the Southern District of California. The former defendant, who is a pro se movant residing in the Middle District of North Carolina, claims that the government is not commencing forfeiture proceedings against the item in question and that she is therefore lawfully entitled to it. ${ }^{4}$ The prosecutor introduced the property into evidence during trial and the former defendant attempted to suppress it, so the trial court has heard extensive evidence related to the property and the underlying search and seizure. In response to the Rule 41(e) motion, the government contends that it still needs the subject property for a prosecution in the Middle District of North Carolina against another individual.' The trial court looks to the first sentence of Rule 41(e), which notes that a person seeking return of seized property "may move the district court for the district in

$\dagger$ A.B. 1997, Harvard University; M.Sc. 1999, The Weizmann Institute of Science; J.D. Candidate 2002, The University of Chicago.

1 FRCrP 18 governs venue in criminal trials. See FRCrP 18 (stating that "the prosecution shall be had in a district in which the offense was committed").

2 Rule 41(e) only pertains to the return of personal and movable property and not real property. See Mark S. Rhodes, 5 Orfield's Criminal Procedure under the Federal Rules $\S 41: 43$ at 706 (Lawyer's Co-op 2d ed 1987) (stating that Rule 41(e) involves the "return of physical objects").

3 The Fourth Amendment requires that the government return property when it no longer needs it, since otherwise the seizure becomes unreasonable. See FRCrP 41, Advisory Committee's Note to the 1989 Amendments (stating that "an aggrieved person may seek return of property that has been unlawfully seized, and a person whose property has been lawfully seized may seek return of property when aggrieved by the government's continued possession of it"). The pertinent part of the Fourth Amendment reads: "The right of the people to be secure in their persons, houses, papers, and effects, against unreasonable searches and seizures, shall not be violated." US Const Amend IV.

4 See FRCrP 54(b)(5) (stating that "[The Federal Rules of Criminal Procedure] are not applicable to ... civil forfeiture of property for violation of a statute of the United States").

5 See FRCrP 41(e) (stating that "reasonable conditions may be imposed to protect access and use of the property in subsequent proceedings"). 
which the property was seized" for its return. ${ }^{6}$ Therefore, despite the apparent suitability of hearing the merits of the motion in the trial court, the judge dismisses the claim and instructs the criminal defendant to refile the motion in the Southern District of California.

Was the decision by the trial court appropriate, or should the court have ruled on the motion since it heard the criminal trial itself? The Fourth ${ }^{7}$ and Tenth $^{8}$ Circuits hold that while the motion is a civil complaint against the government, rather than part of the criminal trial, Rule 41(e) governs.' These courts therefore apply to the motion Rule 41(e)'s venue rules, which they have interpreted to require exclusive venue in the district of seizure. The Second Circuit agrees that the motion is civil in nature, but argues that the trial court may nonetheless hear post-trial motions under the doctrine of ancillary jurisdiction, whether or not the motion is styled under Rule 41(e). ${ }^{10}$ Since it does not reject the possibility that the district of seizure could have heard the motion, the Second Circuit implies that either the trial court or the district of seizure would be a proper venue for a post-trial motion. The Eighth Circuit has agreed with the Second Circuit's use of ancillary jurisdiction, but ruled that the trial court is the only proper venue in which to hear post-trial motions without addressing the potential applicability of Rule 41(e)."

A resolution to the disagreement over the applicability of Rule 41(e) to post-trial motions and the proper venue for these motions is necessary for two reasons. First, Rule 41(e) specifically involves vindication of an important constitutional provision - the right to be free from unlawful searches and seizures. It is therefore extremely important that a court fix the venue for such a motion to facilitate the most accurate adjudication on the merits. The bright-line venue rules proposed by the circuit courts might undermine this goal, and so it is necessary to examine a solution that would achieve it. ${ }^{12}$ Second, without a

6 Id.

7 See United States $v$ Garcia, 65 F3d 17, 20 (4th Cir 1995) (holding that Rule 41(e) applies to post-trial motions for the return of seized property and that the proper venue to hear such motions is the district in which the property was seized).

8 See Clymore v United States, 164 F3d 569, 574-75 (10th Cir 1999) (adopting the Fourth Circuit's interpretation of the venue provisions in Rule 41(e)).

$9 \quad$ See note 17 and accompanying text.

10 See United States v Giovanelli, 998 F2d 116, 118-19 (2d Cir 1993) (determining that the trial court that presided over the underlying criminal proceedings has ancillary jurisdiction to hear a post-trial motion to return property, irrespective of whether it is treated procedurally under Rule 41(e)). For a discussion of the interplay between procedure and jurisdiction in post-trial motions to return property, see Part II.A. For a discussion of ancillary jurisdiction and its role in these motions, see text accompanying notes 34-38 and 73-75.

11 See Thompson v Covington, 47 F3d 974, 975 (8th Cir 1995) (per curiam) (directing a criminal defendant who filed a post-trial motion for return of property in the district of seizure to refile in the trial court because the latter had ancillary jurisdiction to hear the motion).

12 An analogy is the "substantial-contacts test" developed by Second Circuit Judge Ralph 
solution to the disagreement, a situation could arise where there would be a venue gap. For example, if a trial court in the Fourth Circuit ordered a criminal defendant to refile the motion in the district of seizure, which happened to be located in the Eighth Circuit, the postures of the respective circuits would leave the former defendant without a venue for her motion.

This Comment reviews the legislative history of Rule 41(e), which clarifies that post-trial motions for return of property fall within its scope. It also rejects the applicability of ancillary jurisdiction to posttrial motions. The Comment, however, disagrees that Rule 41(e) explicitly directs these motions to the district of seizure. Rather, it argues that while the language and legislative history of Rule 41(e) imply that a single venue is appropriate for post-trial Rule 41(e) motions, neither offers any guidance in choosing between the district of seizure and the district of trial. Therefore, this Comment proposes that courts employ a two-prong test to determine which venue is proper, thereby streamlining the adjudicative process.

Part I explains the operation of Rule 41(e), its legislative background, and the judicial construction of its provisions. It discusses how the Rule's piecemeal drafting history led to the current disagreement among the circuits over the applicability of Rule 41(e) to post-trial motions and the operation of its venue rules. Part II provides a critical analysis of the different circuits' treatments of the jurisdictional basis for post-trial motions to return property and the applicability of Rule 41(e). This Part concludes that Rule 41(e) is the sole procedural tool for post-trial motions to return property and that a single venue is warranted, but that the Rule and its legislative history do not clarify how to determine which venue is suitable.

Part III attempts to resolve the apparent legal dilemmas by formulating a two-prong test to lay the proper venue for post-trial Rule 41(e) motions. The first prong of the proposed test is whether the trial court needs to conduct additional factfinding to rule on the motion. If it does not, then the proper venue is the district of trial. Otherwise, the

Winter to determine the proper venue for a criminal trial under $\mathrm{FRCrP} 18$. See United States $v$ Reed, 773 F2d 477, 481 (2d Cir 1985) (setting forth a balancing test to ascertain where an offense was committed under FRCrP 18, including: "[1] the site of the defendant's acts, [2] the elements and nature of the crime, [3] the locus of the effect of the criminal conduct, and [4] the suitability of each district for accurate factfinding"). Judge Winter developed this balancing test to incorporate the policies inherent in Article III, $\S 2$ and the Sixth Amendment of the Constitution that require courts to conduct criminal trials in the judicial district where the offense occurred. See Charles Alan Wright, 2 Federal Practice and Procedure $\S 301$ at 293-99 (West 3d ed 2000) (explaining that the framers placed extreme importance on a person's right to be tried where he committed the alleged crime). Given that elements of a crime may take place in more than one location, the test functions to find the best district for the trial. For additional discussion of the substantial contacts test, see id $\S 302$ at 309 . 
court must look to the second prong of the proposed test, which involves balancing three criteria: (1) judicial economy; (2) convenience for the government attorney; and (3) the burden on the former defendant. This Part first considers the policies incorporated into Rule 41(e) itself and the criteria used to develop venue rules. It then employs this foundation to formulate the test. Part III concludes by examining applications of the proposed test and reviewing its benefits.

\section{The BACKGRound OF RULE 41(E)}

This Part provides important background information on Rule 41(e). First, it examines the Rule's operation. Second, it reviews the Rule's legislative history, focusing in particular on how the Judicial Conference Advisory Committee ("Advisory Committee") has responded to perceived gaps in Rule 41(e). Finally, this Part discusses the factors leading to the current circuit split and outlines three competing views of the Rule's applicability to post-trial motions and its venue provisions.

\section{A. Rule 41(e)'s Operation}

Rule 41(e) reads as follows:

Motion for Return of Property. A person aggrieved by an unlawful search and seizure or by the deprivation of property may move the district court for the district in which the property was seized for the return of the property on the ground that such person is entitled to lawful possession of the property. The court shall receive evidence on any issue of fact necessary to the decision of the motion. If the motion is granted, the property shall be returned to the movant, although reasonable conditions may be imposed to protect access and use of the property in subsequent proceedings. If a motion for return of property is made or comes on for hearing in the district of trial after an indictment or information is filed, it shall be treated also as a motion to suppress under Rule $12 .{ }^{1.3}$

There are two available grounds for motions to return property under Rule 41(e). First, an individual can claim that the property was unlawfully seized in violation of the Fourth Amendment of the Constitution and that the government therefore has no right to the property. ${ }^{14}$ Additionally, or in the alternative, a movant may assert that the

14 See Mapp v Ohio, 367 US 643, 646-51, 655-57 (1961) (noting that during a criminal proceeding, property that was seized by state or federal officers in violation of the Fourth Amendment should be returned and excluded from evidence). 
property is no longer needed for evidentiary purposes, either because the trial is complete, the defendant has pleaded guilty, or the government has abandoned its investigation. ${ }^{15}$ This second basis is qualified, since courts will not entertain Rule 41(e) motions when the property has been subject to judicial forfeiture. ${ }^{16}$ Interestingly, a motion filed under Rule 41(e) commences a civil proceeding, even though it is contained within the Federal Rules of Criminal Procedure ("Criminal Rules")."

\section{B. Rule 41(e)'s Legislative History}

Rule 41(e) has an intricate legislative history, likely a result of the difficulty of designing procedural rules for criminal law. When the Rule was promulgated, the Advisory Committee noted that although the Rule was primarily a restatement of prior practice, it changed existing law by permitting the motions only before a court and not before either a court or a commissioner subject to review by the court." The Committee stated that the "purpose [of this change was] to prevent multiplication of proceedings," since channeling the motions to a single location was "preferable."

The Rule has since been amended twice in response to perceived inadequacies and unclear language regarding who can make Rule

15 Courts have long held that seized property should be returned to the owner once the government no longer has any need for it. See, for example, United States $v$ Martinson, 809 F2d 1364,1369 (9th Cir 1987) (stating that "[t] sumed to have a right to its return, and the government has the burden of demonstrating that it has a legitimate reason to retain the property").

16 See United States v McGlory, 202 F3d 664, 670 (3d Cir 2000) (stating that Rule 41(e) is inapplicable after criminal proceedings as a means of obtaining review of judicial forfeitures). This holding is based on the language of FRCrP 54(b)(5). See note 4.

17 James Wm. Moore, 27 Moore's Federal Practice \$ 641.194[3] at 641-348 \& n 9 (Matthew Bender 3d ed 1997 \& Supp 2001) (collecting cases). This apparent inconsistency exists because these motions are related to the Fourth Amendment, which outwardly does not implicate criminal matters but, rather, government conduct. However, since governmental searches and seizures often relate to criminal prosecution, the Criminal Rules are an appropriate place for the procedural vehicle to move for their return. Note also that there are a number of other proceedings that may be criminal in nature but are deemed civil, including proceedings to recover fines and penalties. See Mark S. Rhodes, 1 Orfield's Criminal Procedure under the Federal Rules $\$ 1: 4$ at 6 (Lawyers Co-op 2d ed 1985) (providing examples).

18 Consider Jerome Hall, Objectives of Federal Criminal Procedural Revision, 51 Yale L J 723, 728-30 (1942) (discussing the complexity of calibrating criminal procedural rules to give effect to notions of justice in substantive criminal law).

19 The Supreme Court has held that the Advisory Committee's Note to the Federal Rules of Civil Procedure are entitled to interpretive "weight." Torres v Oakland Scavenger Co, 487 US $312,316(1988)$. Some courts defer to the Committee's Note in the context of construing the Criminal Rules. See United States v Downin, 884 F Supp 1474, 1479 (E D Cal 1995) (stating that "the advisory committee notes more accurately reflect actual congressional intent and are thus entitled to greater weight than other forms of legislative history").

20 FRCrP 41, Advisory Committee's Note to the 1944 Adoption. 
41(e) motions and which court should hear them. ${ }^{21}$ Initially, Rule 41(e) simply provided that persons should move for return of seized property in the district of seizure. ${ }^{22}$. However, the Rule was altered in 1972 to address instances when accused criminals made motions for return of property following an indictment, ${ }^{23}$ and the Advisory Committee affirmed that these changes were intended to require that the trial court hear the motions and treat them as motions to suppress evidence. ${ }^{24}$ The idea behind restricting venue to a single location was both to comply with a directive from the Supreme Court ${ }^{25}$ and to comport with the policy notions of judicial economy and convenience to the parties. $^{26}$

Over time, questions arose regarding the applicability of Rule 41(e) to motions outside the context of the criminal trial. Specifically, courts considered whether Rule 41(e) was the appropriate procedural vehicle to make pre- and non-indictment motions for return of property. ${ }^{27}$ Decisions on this matter conflicted greatly. Some courts held that Rule 41(e) applied, ${ }^{28}$ others that it did not, ${ }^{29}$ and still others that

21 See FRCrP 41, Advisory Committee's Note to the 1972 Amendments (dividing Rule 41(e) into Rule 41(e) and 41(f) to deal with motions for return of seized property that are coupled with motions to suppress illegally seized evidence under $\mathrm{FRCrP} \mathrm{12);} \mathrm{FRCrP} 41$, Advisory Committee's Note to the 1989 Amendments (changing the language regarding who may bring Rule 41(e) motions, what the legal standard is for return of property, and who may hear Rule 41(e) motions).

22 See FRCrP 41, Advisory Committee's Note to the 1972 Amendments (noting that under the prior version of the rule, an aggrieved person could only move for return of property in the district of seizure).

23 See id (describing the scope of the amendment).

24 See id (stating that subdivisions (e) and (f) "are intended to require the motion to suppress evidence to be made in the trial court rather than in the district in which the evidence was seized as now allowed by the rule").

25 The Advisory Committee's Note to the 1972 Amendments states that the changes were based on the Supreme Court's decision in DiBella $v$ United States, 369 US 121, 132-33 (1962) (discouraging courts from hearing Rule 41(e) motions in the district of seizure once the criminal trial has begun). FRCrP 41, Advisory Committee's Note to the 1972 Amendments.

26 The Advisory Committee focused on language in DiBella that channeling postindictment Rule 41(e) motions to the trial court will not only "avoid a needless duplication of effort by two courts and provide a more expeditious resolution of the controversy," but also prevent "prejudice either to the Government or to the defendants, or both." FRCrP 41, Advisory Committee's Note to the 1972 Amendments.

27 In general, courts have long assumed jurisdiction to hear motions for return of unlawfully seized property and for suppression of evidence, see Wise v Henkel, 220 US 556, 558 (1911) (ordering return of unlawfully seized property), even when no indictment is pending, see GoBart Importing Co v United States, 282 US 344, 354-55 (1931) (permitting return of property in the absence of an indictment). The relevant issue here is merely the applicability of Rule 41(e). See also Part II.B.

28 See, for example, United States v Martinson, 809 F2d 1364, 1369 (9th Cir 1987) (holding that Rule 41(e) applies to pre-indictment motions for return of property).

29 See, for example, Matter of Search of 4801 Fyler Avenue, 879 F2d 385, 387 (8th Cir 1989) (stating that a court should construe a Rule 41(e) motion prior to the filing of criminal charges as a suit in equity rather than under the Criminal Rules). 
the substance of the motions was the same whether or not brought pursuant to Rule $41(\mathrm{e})$. $^{30}$

In apparent response to this disagreement, Rule 41(e) was amended again in 1989 to eliminate language that the Advisory Committee deemed "confusing." The new version of the Rule affirmed that Rule 41(e) was the appropriate vehicle to address the harm inflicted on nonsuspects. ${ }^{32}$ The Advisory Committee added that the Rule, as amended, "provides that an aggrieved person may seek return of property that has been unlawfully seized, and a person whose property has been lawfully seized may seek return of property when aggrieved by the government's continued possession of it." ${ }^{33} \mathrm{On}$ this account, Rule 41(e) was intended to be the procedural tool for moving in a federal court to return seized property in the absence of an indictment.

\section{The Circuit Split over Application of Rule 41(e) and the Meaning of Its Venue Provisions for Post-Trial Motions for Return of Property}

The 1989 Amendment to Rule 41(e) did not directly address the issue of the Rule's applicability to post-trial motions, probably because they were not the subject of significant debate. Prior to the 1989 Amendment, the few. courts that dealt with the issue assumed they could hear the motions under the doctrine of ancillary jurisdiction. Ancillary jurisdiction allows a court to hear a claim when it would otherwise lack jurisdiction to ensure that the same court handles the case in its entirety and to foster judicial economy. The exercise of ancillary jurisdiction is appropriate when:

30 See, for example, Hunsucker v Phinney, 497 F2d 29, 34 (5th Cir 1974) (holding that it is irrelevant for procedural purposes whether a court analyzes pre-indictment motions for return of property under Rule 41(e)).

31 FRCrP 41, Advisory Committee's Note to the 1989 Amendments.

32 See id (noting that the previous version of the Rule "failed to address the harm that may result from the interference with the lawful use of property by persons who are not suspected of wrongdoing"). The Advisory Committee also stated that the new amendment "conform[ed] the rule to the practice in most districts." Id.

33 Id.

34 See, for example, United States $v$ Wilson, 540 F2d 1100, 1103-04 (DC Cir 1976) (holding that the district court where a criminal defendant was tried could hear his post-trial Rule 41(e) motion because the court's jurisdiction was ancillary to its jurisdiction over the underlying criminal proceedings).

35 See Morrow v District of Columbia, 417 F2d 728, 740 (DC Cir 1969) (discussing the two purposes of ancillary jurisdiction). One should not confuse ancillary jurisdiction with statutory supplemental jurisdiction as codified in 28 USC $\$ 1367$ (1994). The statute requires that the district court have original jurisdiction over an underlying civil action and does not apply when the main proceedings are criminal. See Charles Alan Wright, Arthur R. Miller, and Edward H. Cooper, 13B Federal Practice and Procedure $\S 3567.3$ at 66, 72 n 21 (West 2d ed $1986 \&$ Supp 2000) (stating that "[s]tatutory supplemental jurisdiction does not apply to a criminal case"). 
(1) the ancillary matter arises from the same transaction which was the basis of the main proceeding, or arises during the course of the main matter, or is an integral part of the main matter; (2) the ancillary matter can be determined without a substantial new fact-finding proceeding; (3) determination of the ancillary matter through an ancillary order would not deprive a party of a substantial procedural or substantive right; and (4) the ancillary matter must be settled to protect the integrity of the main proceeding or to insure that the disposition in the main proceeding will not be frustrated.

An exercise of ancillary jurisdiction by the trial court to hear a posttrial motion for return of property inescapably requires that the venue is the district of trial.

For venue purposes, it did not initially matter whether it was appropriate for courts to use ancillary jurisdiction to hear these motions, ${ }^{37}$ since the district of trial and the district of seizure were typically the same. Over time, however, the question arose in instances when the district of trial was different from the district of seizure. In the post-trial context, uncertainty over the application of Rule 41(e) and the meaning of its venue provisions has resulted in a number of divergent interpretations.

\section{The Second Circuit.}

The proper application of Rule 41(e) to post-trial motions was first discussed in United States $v$ Giovanelli. ${ }^{39}$ Although the disputed property was seized in the Eastern District of New York, the Second Circuit determined that the doctrine of ancillary jurisdiction permitted the trial court in the Southern District of New York to hear the criminal defendant's post-trial Rule 41(e) motion. ${ }^{40}$ However, it is not clear from the opinion whether the Giovanelli court believed that Rule 41(e) was the appropriate procedural tool for post-trial motions to return property. The court noted that since the underlying criminal proceedings had concluded, the motion should be treated as a civil equitable proceeding irrespective of whether it was treated procedurally under Rule $41(\mathrm{e}),{ }^{41}$ but it cited to a line of precedent in which

See Morrow, 417 F2d at 740 (setting forth the requirements for ancillary jurisdiction).

38 The pre- and non-indictment debates never considered this issue since, by definition, there was no district of trial.

$39 \quad 998$ F2d 116 (2d Cir 1992).

40 Id at 118-19. See also United States v Leal, 1996 US Dist LEXIS 1309, *3-7 (N D III) (rejecting the Fourth Circuit's "district of seizure" approach to venue in post-trial Rule 41(e) motions and following the reasoning in Giovanelli). The Seventh Circuit has not ruled on the issue.

41 See Giovanelli, $998 \mathrm{~F} 2 \mathrm{~d}$ at 119 (stating that "[w]here criminal proceedings are no longer 
the exercise of ancillary jurisdiction was under Rule $41(\mathrm{e}) .^{42}$ Moreover, the court did not object to the use of Rule 41(e), nor to the idea that the motion could have been heard in the district of seizure. ${ }^{43}$ These apparently conflicting statements result in two possible interpretations: (1) Rule 41(e) applies to post-trial motions and concurrent venue is proper under the Rule; or (2) post-trial motions can be heard in either the district of trial or the district of seizure, but a motion in the district of trial requires use of ancillary jurisdiction and a motion in the district of seizure must be pursuant to Rule 41(e).

\section{The Eighth Circuit.}

In Thompson $v$ Covington, ${ }^{4}$ the Eighth Circuit was faced with a problem similar to that in Giovanelli. ${ }^{45}$ The criminal defendant was tried in the District of Minnesota, but during the criminal investigation the government seized related property in Kansas City. ${ }^{46}$ Following his trial, the defendant moved in the Western District of Missouri for return of the seized property, which the district court rejected on the merits. ${ }^{47}$ On appeal, however, the Eighth Circuit cited Giovanelli without mentioning Rule 41(e) and held that since the motion was a civil matter, the trial court should have heard it under the doctrine of

pending against the defendant such motion is treated as a civil equitable proceeding even if styled as being pursuant to [Rule] 41(e)"), quoting Soviero v United States, 967 F2d 791, 792-93 ( $2 \mathrm{~d}$ Cir 1992). Later, in a case where the districts of trial and seizure were the same, a different Second Circuit panel rejected the use of Rule 41(e) for post-trial motions. See Toure $v$ United States, 24 F3d 444, 445 (2d Cir 1994) ("Toure's complaint, seeking a return of seized property after the conclusion of the underlying criminal case, is [not] properly treated as ... a motion pursuant to [FRCrP] 41(e)."). Rather, it held that they should be treated as commencing a civil action under the Little Tucker Act. See 28 USC $\S 1346$ (a)(2) (1994) ("The district courts shall have original jurisdiction ... [over] any other civil action or claim against the United States, not exceeding $\$ 10,000$ in amount."). However, the Little Tucker Act cannot be a basis of jurisdiction for post-trial motions to return property, since it pertains to claims for monetary damages rather than injunctive relief. See Charles Alan Wright, Arthur R. Miller, and Edward H. Cooper, 14 Federal Practice and Procedure $\S 3657$ at 502-09 (West 3d ed 1998) (stating that as a general matter, the Little Tucker Act only allows claims for damages, not injunctive relief).

42 See Giovanelli, 998 F2d at 119, citing Mora v United States, 955 F2d 156, 158 (2d Cir 1992), for the proposition that a court can hear a post-trial motion under the doctrine of ancillary jurisdiction. Mora cites to United States v Wilson, 540 F2d 1100 (DC Cir 1976), which held that the exercise of ancillary jurisdiction was pursuant to Rule 41(e). See id at 1103-04.

43 In their rejections of the Second Circuit's jurisprudence on post-trial Rule 41(e) motions, the Fourth and the Tenth Circuits interpreted this holding to permit a motion in either the trial court or the district of seizure. See Clymore v United States, 164 F3d 569,574 (10th Cir 1999) (distinguishing between the holdings in Giovanelli and the Eighth Circuit's "district of trial" approach); United States $v$ Garcia, 65 F3d 17, 20 (4th Cir 1995) (same).

4447 F3d 974 (8th Cir 1995) (per curiam).

45 See id at 974 (discussing the factual posture where the district of seizure and the district of trial were not the same).

46 See id.

47 See id at 974-75. 
ancillary jurisdiction. ${ }^{48}$ It therefore directed the defendant to refile the motion in the District of Minnesota, which it described as "the proper district court" for the motion. ${ }^{49}$ In essence, the court rejected the possibility of making a post-trial motion in the district of seizure and stated that the trial court is the exclusive venue for the proceedings. However, since the Thompson court agreed with Giovanelli, which dealt with a post-trial motion made pursuant to Rule 41(e), but did not discuss Rule 41(e) itself, it is not clear from the opinion whether: (1) Rule 41(e) is applicable and its venue provisions compel the district of trial for post-trial motions; ${ }^{50}$ or (2) Rule 41(e) is inapplicable and a court must hear a post-trial motion to return property using ancillary jurisdiction, ${ }^{\text {s1 }}$ which necessitates venue in the trial court.

\section{The Fourth and Tenth Circuits.}

In United States $v$ Garcia $^{52}$ the criminal defendant was tried in the Eastern District of North Carolina, but had been arrested in Florida. During his arrest, the government seized various personal items. After his trial, the defendant moved in the trial court for their return pursuant to Rule 41(e), but the court dismissed for lack of jurisdiction. ${ }^{34}$ On appeal, the Fourth Circuit held that while a post-trial motion for return of property is a civil action, the holdings in Giovanelli and Thompson are contrary to the plain language of Rule $41(\mathrm{e}) .^{55}$ The court asserted that although a "reasonable interpretation" of Rule $41(e)$ is that the trial court has ancillary jurisdiction to hear motions to return property during the trial itself, the first sentence of the Rule clearly directs the motion to the district of seizure at all other times. ${ }^{56}$ Therefore, the court concluded that the district court does not retain ancillary jurisdiction over Rule 41(e) motions following the conclu-

48 Id at 975.

49 Id (emphasis added)

so The Tenth Circuit believes that this is the proper interpretation of the holding in Thompson. See Clymore v United States, 164 F3d 569, 574 (10th Cir 1999) (summarizing the Eighth Circuit's holding that the district court that presided over the criminal matter was "the only proper district to entertain a Rule 41(e) motion") (emphasis added).

51 The Fourth Circuit views this as the correct way to read Thompson. See United States $v$ Garcia, 65 F3d 17, 20 (4th Cir 1995) (noting that the Eighth Circuit held that "a filing in the district of seizure, as required by the rule, is not proper," but did not formulate this posture in the context of Rule 41(e)).

5265 F3d 17 (4th Cir 1995).

53 Id at 18.

54 Id at $18-19$.

55 Id at 19-20. See also United States $v$ Leal, 1996 US Dist LEXIS 1309, *6 (N D Ill) (describing the Fourth Circuit's holding as "[b]ased on a plain reading of rule 41(e) venue language").

56 Garcia, 65 F3d at 20. 
sion of the criminal case and the proper venue for the motions is the district of seizure.

The Fourth Circuit offered two reasons for its interpretation of Rule 41(e). First, the Garcia court looked to Federal Rule of Criminal Procedure 1 ("Rule 1"), which provides that the Criminal Rules apply not only to criminal proceedings, but also "whenever specifically provided in one of the rules, to preliminary, supplementary, and special proceedings before United States magistrate judges and at proceedings before state and local judicial officers." that since Rule 41(e) is contained within the section of the Criminal Rules entitled "Supplementary and Special Proceedings," the civil nature of the proceeding does not bar the applicability of Rule 41(e) and its venue provisions to post-trial motions. Second, the Fourth Circuit looked to the Advisory Committee's Note to the 1989 Amendment for Rule 41(e), and claimed that since the Rule applied to pre- and nonindictment motions to return property, it is also the procedural tool for post-trial motions. ${ }^{60}$ The court therefore suggested that the movant seek return of his property in the Southern District of Florida.

In Clymore $v$ United States, ${ }^{62}$ the Tenth Circuit weighed in on the developing circuit split and agreed with the Garcia court. ${ }^{63}$ The $\mathrm{Cly}$ more court held that when the underlying criminal proceedings have concluded, Rule 41(e) applies to motions to return property and the proper venue is the district of seizure. ${ }^{64}$ It therefore suggested that the criminal defendant, whose criminal trial had taken place in the District of New Mexico, refile in the district of seizure, in Texas. ${ }^{65}$

\section{Problems With THE Courts' Venue Determinations for POST-TRIAL MOTIONS FOR RETURN OF PROPERTY}

The controversy over both the applicability of Rule 41(e) to posttrial motions and the proper venue for these motions results from the Rule's piecemeal drafting history and the use of ancillary jurisdiction. The dispute ultimately reduces to two issues. First, is Rule 41(e) the sole vehicle for making post-trial motions to return seized property? Second, if Rule 41(e) does apply to post-trial motions, how do its

57 Id at 20-21.

58 Id at 20.

59 FRCrP 1.

60 Garcia, $65 \mathrm{~F} 3 \mathrm{~d}$ at 20.

61 Id at 21 (stating that "Garcia's suit should have been brought in the Southern District of Florida").

62164 F3d 569 (10th Cir 1999).

63 Id at 574-75 (noting that "we agree with the Fourth Circuit").

64 Id.

65 Id at 575 (asserting that "the claim should have been dismissed without prejudice to refile in the district of seizure"). 
venue provisions work? This Part examines these two questions. First, it clarifies the jurisdictional basis for adjudicating Rule 41(e) motions. Second, this Part reviews the reasoning of the Fourth Circuit for its use of Rule 41(e) for post-trial motions to return property. It argues that the Rule is the sole avenue of relief to recover seized property in the post-trial context. Finally, it discusses the resulting uncertainty regarding the proper venue for post-trial Rule 41(e) motions.

\section{A. The Jurisdictional Basis Behind Rule 41(e)}

There is no question that a motion to return property seized by federal officers belongs in federal court. ${ }^{66}$ However, the precise jurisdictional basis behind Rule 41(e) motions is not entirely clear-as evidenced by the considerable confusion among authorities regarding the issue. First, some consider Rule 41 (e) as a statutory grant of jurisdiction. ${ }^{67}$ This reasoning is misplaced, since a rule of procedure cannot be the basis of jurisdiction. ${ }^{68}$ Others have asserted that Rule $41(\mathrm{e})$ is based on the equitable jurisdiction of the federal courts. ${ }^{69}$ However, since jurisdiction in the federal district courts is supposed to derive from some act of Congress, the better view is that it either comes from or is directly related to a federal statute. ${ }^{70}$ Therefore, Rule 41(e) likely has one of two jurisdictional sources: general federal criminal jurisdiction," or general federal question jurisdiction. ${ }^{72}$ The primary issue re-

66 See William R. Slomanson, Civil Action for Return of Property: "Anomalous" Federal Jurisdiction in Search of Justification, 62 Denver U L Rev 741, 744 (1985) (noting that "[o]ne practical aspect of this area of the law is nevertheless clear: when property is held by federal officers, aggrieved individuals must seek its return in a federal court").

67 See, for example, Rhodes, 5 Orfield's Criminal Procedure § 41:43 at 707 n 13 (cited in note 2) ("Rule 41(e) can be the basis for federal court jurisdiction.").

68 See Washington-Southern Navigation Co v Baltimore \& Philadelphia Steamboat Co, 263 US 629, 635 (1924) ("[N]o rule of court can enlarge or restrict jurisdiction."). See also Rules Enabling Act, 28 USC $\S 2072$ (b) (1994) (stating that rules of procedure in the federal courts "shall not abridge, enlarge or modify any substantive right"). There is a plausible argument that a rule of procedure can define the scope of jurisdiction of the federal courts in the absence of a congressional statute. See Michael J. Edney, Comment, Preclusive Abstention: Issue Preclusion and Jurisdictional Dismissals after Ruhrgas, 68 U Chi L Rev 193, 219 \& n 135 (2001) (arguing that FRCP 4(k)(1)(A) may "enlarge" personal jurisdiction because Congress has not provided otherwise). However, in the case of Rule 41(e), there are statutory bases for jurisdiction, and hence this position is inapplicable.

69 See, for example, Smith v Katzenbach, 351 F2d 810,815 (DC Cir 1965) ("[Rule 41] is a crystallization of a principle of equity jurisdiction.").

70 See Charles Alan Wright, Arthur R. Miller, and Edward H. Cooper, 13 Federal Practice and Procedure $\$ 3522$ at $61 \mathrm{n} 2$ (West 2d ed 1984) ("Due regard for the rightful independence of state governments, which should actuate federal courts, requires that those courts scrupulously confine their own jurisdiction to the precise limits that a federal statute has defined.") (citation omitted).

71 See 18 USC $\$ 3231$ (1994) ("The district courts of the United States shall have original jurisdiction, exclusive of the courts of the States, of all offenses against the laws of the United States."). Jurisdiction over Rule 41(e) motions could be derived from this grant. See James C. 
garding post-trial motions for return of property, however, is whether Rule 41(e) is the sole procedural vehicle for accessing federal jurisdiction in the post-criminal trial context. If it is, then the Rule's venue provisions apply.

However, irrespective of the Rule's applicability, ancillary jurisdiction can never be a basis of jurisdiction to hear post-trial motions for return of property. First, it is never possible to fulfill the requirement that a court must hear the ancillary matter so as not to frustrate the main disposition. ${ }^{73}$ Motions for return of property are civil proceedings that are not part of the criminal trial, ${ }^{74}$ and whether or not a court returns seized property is independent of the ultimate judgment of guilt or innocence in the criminal case if the property is not being forfeited. Second, ancillary jurisdiction involves the assertion of jurisdiction over: (1) claims for which the federal court lacks independent subject matter jurisdiction; or (2) disputes involving nonparties to the main proceeding. ${ }^{75}$ As discussed above, however, there are statutory bases for federal subject matter jurisdiction over post-trial motions to return property, and the motions do not involve third parties. Therefore, the Second and Eighth Circuits were incorrect to advocate use of ancillary jurisdiction for post-trial motions to return property, and courts should not apply the doctrine in this coniext.

\section{B. The Applicability of Rule 41(e) to Post-Trial Motions}

The first issue for resolution is the scope of Rule 41(e). The Fourth Circuit, the only circuit to explain its use of Rule 41(e) for post-trial motions, posited two reasons for applying Rule 41(e). The first rationale was based on the language of Rule $1 .^{76}$ The court stated that while post-trial motions for the return of property are civil proceedings, the appendix to the Criminal Rules lists Rule 41(e) under "Supplementary and Special Proceedings," and therefore Rule 1 shows that the Criminal Rules apply because it states that they govern the procedure for supplementary and special proceedings.

Colihan, Note, Mason v. Pulliham and Anomalous Jurisdiction: Stating a Claim and Obtaining Jurisdiction to Assert Fourth Amendment Violations When No Indictment Is Pending, 64 Va L Rev $85,90 \mathrm{n} 50$ (1978) (arguing for such derived powers).

72 See 28 USC $\$ 1331$ (1994) ("The district courts shall have original jurisdiction of all the civil actions arising under the Constitution, laws, or treaties of the United States."). See also Slomanson, 62 Denver U L Rev at 752-54 (cited in note 66) (arguing that federal question jurisdiction is the basis of pre-indictment motions for return of property).

73 See text accompanying note 36 .

74 See note 17 and accompanying text.

75 See Moore, 16 Moore's Federal Practice $\$ 106.03$ [4] at 106-13 to 106-15 (cited in note 41) (describing the purpose and use of ancillary jurisdiction).

76 Garcia, 65 F3d at 20 (analyzing the text of Rule 1).

77

Id. 
This reasoning for the applicability of Rule 41(e), however, is not correct. A close examination of Rule 1 shows that the Garcia court misread it. Rule 1 provides:

These rules govern the procedure in all criminal proceedings in the courts of the United States as provided in Rule 54(a); and, whenever specifically provided in one of the rules, to preliminary, supplementary, and special proceedings before United States magistrate judges and at proceedings before state and local judicial officers.

Looking at Rule 1 in its entirety, it says that the Criminal Rules apply to supplementary and special proceedings that are before magistrate judges. ${ }^{79}$ Therefore, under the Fourth Circuit's reading, for Rule 41(e) to apply to post-trial motions because it is either a supplementary or a special proceeding would seem to require that the motions only be heard by magistrate judges and not Article III judges, which is not how the Rule is administered. ${ }^{80}$ Thus, the Garcia court's Rule 1based reasoning for the applicability of Rule $41(\mathrm{e})$ to post-trial motions is not persuasive.

The second justification for the application of Rule 41(e) considered by the Garcia court comes from Rule 41(e)'s legislative history. ${ }^{81}$ In its note to the 1989 Amendments, the Advisory Committee asserted that the Rule is intended to cover "harm that may result from interference with the lawful use of property by persons who are not suspected of wrongdoing." If the language of Rule 41(e) is broad enough to include an unindicted movant's claim for return of seized property, then it should certainly apply to a post-trial motion, which is more closely connected to criminal matters. In addition, the Advisory Committee stated that Rule 41(e), as amended, "provides that ... a person whose property has been lawfully seized may seek return of property when aggrieved by the government's continued possession of

78 FRCrP 1.

79 An example is Rule 41(a), which explicitly discusses proceedings before "a magistrate judge." FRCrP 41(a).

80 Rule 41(e) proceedings may be conducted before Article III judges or magistrates. The Rule's language was changed from "judge" to "court" in the second sentence to permit both a magistrate and a district court judge to make findings on a motion for return of property; the Rule thus encompasses magistrates whenever it uses the word "court." See FRCrP 41, Advisory Committee's Note to the 1989 Amendments. See also Matter of Search of 4330 North 35th Street, 142 FRD 161, 165 (E D Wis 1992) (noting that both magistrates and district court judges may exercise jurisdiction over motions for seized property because of the word "court" in Rule 41(e)).

81 See Garcia, 65 F3d at 20 (reviewing the Advisory Committee's Note to the 1989 Amendments to Rule 41(e)).

82 FRCrP 41, Advisory Committee's Note to the 1989 Amendments. See notes 31-33 and accompanying text. 
it." ${ }^{83}$ This language appears to relate directly to a post-trial situation where the government no longer needs the property and the criminal defendant is legally entitled to its return. ${ }^{84}$ Therefore, Rule 41(e) is applicable to post-trial motions for return of property, and the Fourth Circuit's holding on this issue was correct despite some problems with its reasoning.

Moreover, if Rule 41(e) applies to post-trial motions to return seized property, there are two reasons why it is therefore the sole procedural vehicle for this action. First, although procedural rules apply to the full range of cases within a federal court's jurisdiction, it is logical that if Congress specifically promulgated a rule to enforce a particular constitutional right, then one should utilize that rule to the exclusion of others when making the pertinent claim. Second, even if an individual used the Federal Rules of Civil Procedure to bring an action for return of property, ${ }^{86}$ the venue provisions of Rule 41(e) would still apply. The general venue statute sets forth the proper venue for civil actions against the United States, its agencies, and its officers, "except as otherwise provided by law." "If Rule 41(e) applies to post-trial motions for return of property, then it functions as an exception to the general venue statutes and restricts the permissible locations. Therefore, a court should treat any post-trial motion to return property as a motion pursuant to Rule 41(e).

\section{The Venue Provisions of Rule 41(e)}

Because Rule 41(e) is the procedural device to move for return of property, a court adjudicating such a motion must interpret the Rule's venue requirements. This necessitates an examination of the Rule's structure and legislative history.

\section{Rule 41(e) encompasses two potential judicial districts.}

The first sentence of Rule 41(e) reads that a person "may move the district court in which the property was seized." ${ }^{, 88}$ This appears to be the default venue provision. The latter part of the Rule, however, provides that the motion can be made "in the district of trial." ${ }^{, 89}$ Therefore, as a general matter, the language of Rule 41(e) presents two conceivable locations where it is possible to bring a motion to return

83 Id.

84 See notes 14-15 and accompanying text.

85 See, for example, FRCrP 1 ("These rules govern the procedure in all criminal proceedings in the courts of the United States.").

86 See FRCP 3 ("A civil action is commenced by filing a complaint with the court.").

8728 USC \$ 1391(e) (1994).

88 FRCrP 41(e).

89 Id. 
seized property. The question then becomes whether one of these two judicial districts is the only proper venue in certain instances.

2. Rule 41(e) is silent with respect to post-trial motions.

When a motion is made following an indictment but still during trial, the Rule limits venue to the trial court. ${ }^{90}$ Pre- and non-indictment motions will take place in the district of seizure, since by definition there is no district of trial. However, Rule 41(e) itself does not directly address post-trial motions. The Fourth Circuit argued that the default venue provision of the district of seizure applies." Although this reasoning is persuasive, it is not entirely compelling. The Rule's first sentence does not require that the motion be made in the district of seizure except in certain circumstances. It only permits a person to move in the district of seizure; it does not mandate that a person move in the district of seizure. ${ }^{92}$ Moreover, the Rule's legislative history does not specifically address the proper venue for post-trial motions. Thus while Rule 41(e) clearly specifies venue to hear the motions during trial and in pre- and non-indictment instances, it fails to do so for posttrial motions.

\section{Concurrent venue for post-trial motions is not warranted} from this silence.

At first glance, this conclusion supports the idea that Rule 41(e) mandates concurrent venue for post-trial motions. However, three reasons support limiting post-trial motions to a single proper venue. First, since the Rule limits motions to a single proper venue in preand non-indictment scenarios and during the criminal trial itself, laying venue in one location for post-trial motions makes the rule internally consistent. ${ }^{93}$ Second, Rule 41(e)'s legislative history demonstrates the Advisory Committee's commitment to developing a single proper venue for motions under the Rule. Third, given both the constitu-

90 This is only evident from looking at both Rule $41(\mathrm{e})$ and its legislative history. See notes 31-33 and accompanying text.

91 See notes 55-57 and accompanying text.

92 See Garcia, 65 F3d at 21 (Murnaghan dissenting) (rejecting the argument that Rule 41(e) limits venue to the district of seizure). See also United States $v$ Leal, 1996 US Dist LEXIS $1309, * 6-7$ (N D III) (asserting that Rule 41(e) does not require that a movant file only in the district in which property was seized).

93 Consider John E. Coons, Consistency, 75 Cal L Rev 59, 59-65 (1987) (arguing for consistency in the interpretation of rules).

94 See FRCrP 41, Advisory Committee's Note to the 1944 Adoption (stating that the new rule was adopted to "prevent multiplication of proceedings" by limiting the forum for Rule 41(e) motions to a court). In the Note to the 1972 Amendments, the Committee maintained that it redrafted the Rule to restrict post-indictment motions to the trial court. See notes 23-26 and accompanying text. 
tional concerns implicated by Rule 41(e) itself and the principles behind venue rules," the factual background of a Rule 41(e) motion will virtually always favor hearing the motion in one judicial district over the other. ${ }^{\circ}$ Even the Giovanelli court, which appeared to allow venue in multiple courts, recognized that the "facts" of that case made the trial court the suitable location to adjudicate it." Therefore, post-trial Rule 41(e) motions should have a single proper venue. However, given the lack of direction from both Rule 41(e) and its legislative history, an exploration of what "facts" might direct the motion to one judicial district rather than the other is warranted.

\section{A Two-Prong Test to Determine Proper VENUE fOR POST-TRIAL RULE 41(E) MOTIONS}

Rule 41(e) is the sole procedural vehicle for post-trial motions to return seized property, and such motions should fix venue in a single location. However, neither the Rule nor its legislative history provides guidance as to which judicial district is proper. This Part proposes a two-prong test to resolve this issue. First, this Part examines both the constitutional concerns incorporated into Rule 41(e) and the principles for crafting venue rules in order to establish a policy foundation for the test. Second, it sets forth and explains the test: (1) if the trial court has heard evidence relevant to the motion such that additional factfinding is unnecessary, then the district of trial is the proper venue; (2) otherwise, the court should balance three criteria to ascertain venue: (a) judicial economy; (b) convenience for the government attorney; and (c) the burden on the former defendant. Finally, this Part explains the application of the proposed test and discusses its benefits.

\section{A. Policy Considerations Behind the Two-Prong Test}

There are two relevant factors in formulating a test to set the proper venue for post-trial Rule 41(e) motions. First, Rule 41(e) involves vindication of an important constitutional right-namely the guarantee against unreasonable searches and seizures under the Fourth Amendment. Therefore, the lodestar in laying venue should be accurate adjudication on the merits rather than mere procedural clar-

95 Part III.A addresses this position and uses these policy considerations to formulate the proposed solution. It argues two points. First, because Rule $41(\mathrm{e})$ involves vindication of a constitutional right, it is critical that venue lay in the court that will most accurately adjudicate the motion. Second, given that Rule 41(e) motions are hybrid civil-criminal proceedings, the policies that inform the development of venue rules should be judicial economy and fairness to both parties.

96 See Part III.C for a discussion of how to apply the proposed test.

97 Giovanelli, $998 \mathrm{~F} 2 \mathrm{~d}$ at 119 (stating that the exercise of ancillary jurisdiction in order to hear the motion in the district of trial "is especially appropriate on the facts here before us"). 
ity, a goal implicit in the bright-line rules advocated by the circuit courts. $^{98}$ Moreover, it is acceptable to interpret Rule 41(e) in this manner because it is a Federal Rule of Criminal Procedure, and therefore courts should construe it in light of underlying policy objectives ${ }^{99}$ instead of to promote simplicity, as required for the Rules of Civil Procedure.

Second, it is necessary to illuminate what criteria will ensure that a test to determine venue for post-trial motions will comport with this principle. There are three relevant considerations: (1) judicial economy; (2) fairness to the government attorney; and (3) fairness to the former defendant. There are two reasons why these factors should govern. First, the Advisory Committee has used these criteria to lay venue for Rule 41(e) motions in other instances. ${ }^{101}$ Second, given that Rule 41(e) implicates both civil and criminal venue concerns, ${ }^{102}$ these three standards represent the sum total of the principles used to develop civil and criminal venue rules. Civil venue rules function to promote judicial economy ${ }^{103}$ and convenience to the defendant, ${ }^{104}$ which in this case is the government. Criminal venue rules, on the other hand, operate to foster fairness to the criminal defendant. ${ }^{105}$

98 See Part I.C.

99 See Fallen v United States, 378 US 139, 142 (1964) (stating that the Criminal Rules "are not, and were not intended to be, a rigid code to have an inflexible meaning irrespective of the circumstances"); Charles Alan Wright, 1 Federal Practice and Procedure $\S 32$ at 32-33 (West 3d ed 1999) ("[The Criminal Rules] are not to be applied ritualistically, but are to be construed in the flexible spirit contemplated by [FRCrP] 2."); Rhodes, 1 Orfield's Criminal Procedure $\$ 2: 4$ at 32 (cited in note 17) (same); Alexander Holtzoff, ed, Federal Rules of Criminal Procedure with Notes and Institute Proceedings 120-21 (NYU Law 1946) ("[FRCrP] 2 expresses the spirit that is intended to motivate the application of all the sixty rules promulgated by the Supreme Court and to make it very clear that they are not in any case to be interpreted technically so as to defeat the ends of justice.").

100 See Amchem Products, Inc $v$ Windsor, 521 US 591, 620 (1997) (stating that courts must not use "judicial inventiveness" to overcome "the text of a rule").

101 In its Note to the 1972 Amendments, the Committee stressed that the trial court was the sole proper venue for motions made during trial because it would "provide a more expeditious resolution of the controversy" and prevent "prejudice either to the Government or the defendants, or both." FRCrP 41, Advisory Committee's Note to the 1972 Amendments.

102 See Matthews v United States, 917 F Supp 1090, 1100 (E D Va 1996) (noting that when a person makes a post-trial Rule 41(e) motion, a "strict division between civil and criminal proceedings does not exist"); Slomanson, 62 Denver U L Rev at 741 (cited in note 66) (referring to Rule 41(e) as a "hybrid civil-criminal procedural vehicle").

103 See Charles Alan Wright, Arthur R. Miller, and Edward H. Cooper, 15 Federal Practice and Procedure $\$ 3801$ at 3 n 4 (West $2 \mathrm{~d}$ ed 1986) (noting that civil venue provisions are "designed to protect... courts from inconvenient lawsuits").

104 See Leroy v Great Western United Corp, 443 US 173, 183-84 (1979) (stating that civil venue rules are generally designed to protect the defendant against the risk that a plaintiff will select an unfair or inconvenient place of trial).

105 See James Wm. Moore, 25 Moore's Federal Practice $\$ 618.02$ at 618-8 (Matthew Bender 3d ed 1997 \& Supp 2001) (noting that criminal venue provisions operate to "protect[ ] federal defendants from unfairness and hardship in defending themselves against federal prosecutors"). 
Therefore, any proposed venue should revolve around these three factors.

\section{B. The Two-Prong Test}

1. If the trial court has already conducted all the relevant factfinding, then the proper venue is the district of trial.

Given the aforementioned policy considerations, if the trial court has already reviewed evidence on the subject property to the extent that it does not need to engage in additional factfinding, then judicial economy concerns are dispositive and the trial court should hear the motion. The reason one factor should be outcome determinative in certain circumstances is to make the proposed test consistent with other multifactor analyses to determine the proper venue under a Criminal Rule. ${ }^{106}$ If there must be a dispositive factor, there are two arguments why complete factfinding by the trial court should determine venue in the case of Rule 41(e) motions. First, the main task of a court in adjudicating a Rule 41(e) motion is to make the relevant findings of fact. ${ }^{107}$ Given this specification, it seems that if the trial court has already conducted the necessary factfinding, then its consequent ability speedily to resolve the matter points towards fixing venue in the district of trial. ${ }^{108}$ Second, courts often indicate that judicial economy is the key issue in laying venue for post-trial Rule 41(e) motions, and complete factfinding by the trial court will only maximize the weight of this concern.

2. If the trial court needs to conduct additional factfinding, then a balancing test should determine venue.

However, if the trial court needs additional facts to adjudicate the motion, then it should determine venue by balancing three considerations: (1) judicial economy; (2) convenience for the government attorney; and (3) the burden on the former defendant.

106 In Platt $v$ Minnesota Mining \& Manufacturing Co, 376 US 240 (1964), the Supreme Court set forth a ten-prong balancing test for transfers of venue under FRCrP 21(b). See id at 243-44. Four of these factors are "generally decisive." Moore, 25 Moore's Federal Practice $\S 621.04[4][\mathrm{b}]$ at $621-22 \mathrm{n} 15$ (cited in note 105). However, if the four dispositive criteria "do not clearly point to a particular district as the proper FRCrP 21(b) venue," then courts must consider all ten factors to lay venue. Id $\$ 621.04[4][\mathrm{c}]$ at $621-24$.

107 See FRCrP 41(e) ("The court shall receive evidence on any issue of fact necessary to the decision of the motion.").

108 The standard governing the dispositive factors is whether they clearly point to a particular district as the proper venue. See note 106 and accompanying text.

109 See Clymore, 164 F3d at 575 (claiming that laying venue in the district of seizure will "conform[ ] more closely to ... the practicalities of judicial administration"); United States v Leal, 1996 US Dist LEXIS 1309, *7 (N D Ill) (maintaining that hearing the motion in the trial court comports with "judicial economy objectives"). 
a) Judicial economy. The primary factor a court should examine to gauge the gravity of the judicial economy concerns is the extent of the necessary factfinding. If it is marginal, this criterion points towards hearing the case in the district of trial, but if it is considerable, it militates in favor of the district of seizure. More precise factors a court might consider are: (1) the location of possible witnesses; (2) the location of documents and records likely to be involved; and (3) the docket condition of the relevant districts or divisions. ${ }^{110}$

b) Convenience for the government attorney. The specific issue here is whether the government has a continued need for the subject property beyond the criminal trial. ${ }^{111}$ Rule $41(\mathrm{e})$ explicitly provides for these contingencies, and permits a court to condition the return of property on future access for and use by the government in subsequent proceedings. ${ }^{12}$ If the government has a continuing need for the property, it favors hearing the motion in the relevant judicial district, since this will enable the prosecutor who will require the property to argue the motion. However, this factor becomes a nullity if the government does not need the property ${ }^{113}$ or requires the property in a location that is within neither the district of trial nor the district of seizure. $^{1.4}$

c) Burden on the former defendant. The choice of venue should act to minimize potential difficulties for the former defendant in presenting her arguments. Therefore, a court should assess whether hearing the motion in another district will impose a substantial additional burden on the former defendant. The issues a court might consider for this determination are: (1) the location of the former defendant; (2) the location of counsel, ${ }^{\text {is }}$ if the former defendant has representation;

110 These criteria are three of the Platt factors. See Platt $v$ Minnesota Mining \& Manufacturing Co, 376 US 240, 243-44 (1964).

111 Examples include subsequent criminal prosecutions against other individuals and civil actions that follow a criminal prosecution, such as a civil antitrust suit, both of which may require the subject property for evidentiary purposes.

112 See FRCrP 41(e) ("[R]easonable conditions may be imposed to protect access and use of the property in subsequent proceedings.").

113 An assertion by the government that it has no need for the claimed property does not mean that adjudication of the motion is a mere formality. A court may still have to determine whether the government actually seized the property or if the government returned the items in question. The court will also have to decide whether the property belongs to the former defendant. See the FRCrP 41, Advisory Committee's Note to the 1989 Amendments ("As amended, subdivision (e) provides for a return of the property if the person is entitled to lawful possession."). See also Charles Alan Wright, 3 Federal Practice and Procedure $\$ 673$ at 763 (West 2d ed 1982) (noting that a movant under Rule 41(e) "must show that he is entitled to lawful possession of the [subject] property").

114 Since Rule 41(e) only discusses two types of judicial districts, the district of seizure and the district of trial, see Part II.C.1, to hear the motion in a third district would be beyond the Rule's scope.

115 The location of the defendant and the location of counsel are two of the Platt factors. 
and (3) whether the defendant is a pro se movant, ${ }^{116}$ which is a common occurrence. ${ }^{117}$

\section{Application of the Two-Prong Test}

Applying the test to the introductory hypothetical ${ }^{118}$ demonstrates how one could determine venue using the first prong of the proposed test - since the trial court already conducted all the necessary factfinding during the criminal trial, it should rule on the motion. However, even if the trial court had not reviewed any relevant evidence whatsoever, the district of trial would still be the proper venue. Looking to the second prong of the proposed test, since the government had a continuing need for the property in the district of trial and the former defendant was a pro se movant residing in the same district, these two factors would outweigh any judicial economy concerns that may point towards the district of seizure.

Giovanelli $^{119}$ is an example of a case that would be settled on the first prong. Since the trial court appears to have examined all the facts relevant to the property at issue, ${ }^{120}$ the proposed test directs the motion towards the district of trial. Thompson, ${ }^{121}$ however, would require use of the second prong of the test. Assuming that additional facts were necessary, ${ }^{122}$ the factual posture warranted keeping the motion in the district of seizure: (1) evidence documenting and relating to all of the subject property was in the district of seizure; ${ }^{123}(2)$ the government no longer needed the property, ${ }^{124}$ rendering convenience to the government a nullity; and (3) the former defendant was a pro se movant ${ }^{125}$ who sought return of the property in the district of seizure.

If after applying the proposed test a court determines that the present venue is improper, it should transfer the motion to the other

See note 106.

116 See Haines $v$ Kerner, 404 US 519, 520 (1972) (holding that a court should treat a pro se plaintiff's pleadings and papers under "less stringent standards").

117 See, for example, Clymore, 164 F3d at 570 (noting that the movant was pro se); Garcia, 65 F3d at 19 (same); Thompson, 47 F3d at 974 (same).

118 See text accompanying notes $1-6$.

$119998 \mathrm{~F} 2 \mathrm{~d} 116$.

120 Id at $117-18$.

$121 \quad 47$ F3d 974.

122 Since the defendant alleged that the seizure violated his constitutional rights, it is likely that the trial court did not review evidence related to the seizure, because otherwise it would have previously ruled on the constitutionality of the seizure. See id at 974 ("Thompson alleged that the seizure violated his constitutional rights.").

123 Id ("[T]he property was inventoried in Kansas City.").

124 Presumably, since the government "assert[ed] that it [could not] find [the movant's] property," it no longer had a compelling need for the items. Id at 975.

125 Id at 974 (noting that the movant was pro se). 
district under 28 USC $\S 1406(a) .{ }^{126}$ There are two reasons why the court should transfer the case rather than dismiss the motion and order the former defendant to refile. ${ }^{127}$ First, 28 USC $\S 1406$ (a) requires that a court transfer a case "if it be in the interest of justice." Rule 41(e) motions, the factors that would render a transfer contrary to "the interest of justice" will rarely, if ever, be relevant. ${ }^{129}$ Second, transferring the case will cure any possibility of a venue gap, since the transferee court is not supposed to reexamine the transfer decision under this statute ${ }^{130}$ meaning that it should proceed to adjudication rather than use the proposed test to reconsider venue. In the highly unlikely situation that a court determines the balance is in equipoise, it should afford more weight to the judicial economy factor because the level of factfinding by the trial court, a subset of this consideration, may be dispositive under the first prong of this test. ${ }^{131}$

\section{Benefits of the Two-Prong Test}

There are three primary benefits of the proposed test. First, it is similar to other tests for determining the proper venue under the Criminal Rules, such as the test in Platt v Minnesota Mining \& Manufacturing $\mathrm{Co}^{132}$ for transfers of venue under Federal Rule of Criminal Procedure 21(b), ${ }^{133}$ and Judge Ralph Winter's test for laying venue in

126 "The district court of a district in which is filed a case laying venue in the wrong division or district shall dismiss, or if it be in the interest of justice transfer such case to any district or division in which it could have been brought." 28 USC $\$ 1406$ (a) (1994). The transfer should be sought under 28 USC $\S 1406$ (a), as opposed to 28 USC $\S 1404$ (a), because the latter deals with situations when there is a better venue for the motion. See 28 USC 1404(a) (1994) ("For the convenience of the parties and witnesses, in the interest of justice, a district court may transfer any civil action to any other district or division where it might have been brought."). In the case of post-trial Rule 41(e) motions, there is only a single proper venue for the motion and hence any other judicial district would be an improper venue.

127 See Clymore, 164 F3d at 575 (dismissing the claim and ordering the movant to refile in the district of seizure); Garcia, 65 F3d at 21 (same); Thompson, 47 F3d at 975 (dismissing the claim and ordering the movant to refile in the district of trial).

12828 USC $\S 1406(a)$.

129 The three factors are whether the plaintiff brought the motion in the wrong district: (1) for some improper or bad faith purpose; (2) to harass the defendant with litigation in a remote forum; and (3) to forum shop. James Wm. Moore, 17 Moore's Federal Practice $\$ 111.34[3]$ at 111165 (Matthew Bender 3d ed 1997 \& Supp 2001).

130 This is true even if the transfer were done under 28 USC $\$ 1404(a)$. See Wright, Miller, and Cooper, 15 Federal Practice and Procedure $\$ 3827$ at 276 (cited in note 103) (noting that, for transfers under 28 USC $\S 1406(a)$, "[t $t$ he doctrine of law of the case applies. . . There should never be any reason for the transferee court to reexamine the decision of the transferor court that venue was improper in that district, since even if that decision were incorrect the transfer could have been ordered under \$ 1404(a).").

131 See Part III.B.1.

132376 US 240 (1964).

133 See note 106 (discussing the operation of the Platt test). 
criminal trials under Federal Rule of Criminal Procedure $18 .{ }^{1.34}$ Second, it incorporates the concerns related to the constitutional issues invoked by Rule 41(e) motions and the principles behind the formulation of the relevant venue rules. Finally, use of the test will eliminate the possibility of a venue gap that exists under the current circuits' holdings. Although it is not necessary that an amendment codify the test in Rule $41(\mathrm{e})$, such action would obviously give credibility to its employment by courts. ${ }^{135}$

\section{CONCLUSION}

The patchwork language of Rule 41(e) makes it difficult to apply. Courts have therefore disagreed over both the applicability of Rule 41(e) to post-trial motions and the proper venue for such motions. This Comment suggests that Rule 41(e) is the sole procedural device to make post-trial motions for return of seized property. However, the Comment also rejects the notion that the Rule always directs posttrial motions to the same venue. Rather, it argues that while limiting the venue to one district is appropriate, neither Rule 41(e) nor its legislative history specifies where to lay venue in the post-trial context. It therefore develops a two-prong test that will channel these motions to the appropriate judicial district. This test should assist courts in reaching an accurate resolution of post-trial Rule 41(e) motions on their merits.

134 Judge Winter uses a balancing test to determine venue under FRCrP 18. For a discussion of Judge Winter's "substantial-contacts test," see note 12. Moreover, use of a balancing test itself is an appropriate tool to determine venue, since the Criminal Rules were drafted with the intention of "balancing the public interest on the one hand and the rights of the defendant on the other." Wright, 1 Federal Practice and Procedure $\$ 3$ at 8 (cited in note 99) (emphasis added).

135 The Advisory Committee is considering making wholesale changes to $\mathrm{FRCrP} 41$, including Rule 41(e). The proposal is in the initial stages of review by the Advisory Committee and has yet to be sent to the Standing Committee on Rules of Practice and Procedure. Should the Standing Committee approve the proposed amendment, it will have to be subsequently approved by the Judicial Conference, the Supreme Court, and ultimately Congress before it will take effect. For a discussion of the amendment process, see Wright, 1 Federal Practice and Procedure $\$ 4$ at 15-16 (cited in note 99). In its current format, the proposed amendment is very problematic. It requires that individuals move in the district of seizure to return property, thereby ignoring not only the problems that would develop if the motion were made during trial, as addressed by the 1972 Amendment, but also the policy issues discussed in Part III.A of this Comment. The Advisory Committee does not offer any reason for the changes. It is quite possible, given the number of stages remaining in the amendment process, see Wright, 1 Federal Practice and Procedure $\$ 4$ at 20-22, that the proposed changes will not take effect, or at least not in their current form. In the interim, courts should interpret post-trial Rule 41(e) motions consistent with the test proposed in Part III.B. Those involved in the rulemaking process should incorporate the test into the amendment. To the extent that any amendment is ambiguous with respect to post-trial motions, courts should interpret the new rule consistent with the approach advocated by this Comment. 


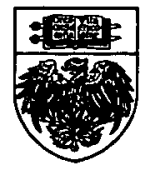

